\title{
Apakah kombinasi power lbp dan fourier descriptor dapat digunakan untuk klasifikasi citra kerang?
}

\author{
Putri Aisyiyah Rakhma Devi' $^{1)}$, Nanik Suciati ${ }^{2)}$ dan Wijayanti Nurul Khotimah ${ }^{3)}$ \\ Teknik Informatika, Institut Teknologi Sepuluh Nopember \\ Jl. Raya ITS, Kampus ITS, Sukolilo, Surabaya \\ e-mail: putriaisyiyah@gmail.com ${ }^{1)}$, nanik@if.its.ac.id ${ }^{2)}$, wijayanti@if.its.ac.id $^{3)}$
}

\section{Info Artikel}

Diserahkan 22 Juli 2016, direvisi 16 Desember 2016, diterima 21 Maret 2017, tersedia online 25 Maret 2017

\begin{abstract}
ABSTRAK
Permasalahan pengklasifikasian secara manual biasanya terletak pada hasil akurasi dan waktu klasifikasi. Pengklasifikasi citra kerang pada umumnya dilakukan berdasarkan pada karakteristik bentuk dan tekstur cangkang kerang. Pengembangan perangkat lunak untuk pengklasifikasian secara otomatis diharapkan dapat meningkatkan hasil akurasi dan memperbaiki waktu klasifikasi. Pada penelitian ini bertujuan untuk mengkombinasikan fitur tekstur berbasis metode Power LBP dan fitur bentuk berbasis metode Fourier Descriptor yang digunakan untuk klasifikasi citra kerang. Citra input yang digunakan, sebelumnya telah melalui praproses dan segmentasi untuk memisahkan objek dengan background. Citra objek yang sudah terpisah ditransformasi menjadi citra biner dan citra grayscale untuk proses ekstraksi fitur. Hasil dari kedua fitur yang sudah diperoleh akan dilakukan kombinasi dengan mempertimbangkan bobot masingmasing fitur yang kemudian dilakukan normalisasi. Dengan mengkombinasikan fitur tekstur dan fitur bentuk diharapkan memperoleh fitur yang signifikan yang dapat meningkatkan akurasi sebuah klasifikasi. Uji coba dilakukan pada 3 jenis dataset kerang yakni kerang darah, kerang pasir dan kerang bulu dengan menggunakan SVM cross validation dengan $k=2$. Hasil uji coba menunjukkan bahwa ada keterkaitan antara mengkombinasikan fitur tekstur dan fitur bentuk pada permasalahan klasifikasi citra kerang dapat diperbaiki dengan hasil akurasi klasifikasi yang diperoleh sebesar 99,39\% dengan fitur tekstur lebih dominan daripada fitur yang lainnya.
\end{abstract}

Kata kunci: Citra kerang; ekstraksi fitur; Fourier Descriptor; klasifikasi; Power LBP.

\section{ABSTRACT}

Shells image classification are generally conducted based on the characteristics of the shape and texture of the shells. The problems of classification usually occur results of accuracy and timing classification. The software development for classification is expected to increase the yield of accuracy result and optimize the time of classification. In this study, we combine extracting texture features based Power LBP method and extracting shape features based Fourier Descriptor method for shells image classification. The used input images had been conducted preprocessing and segmentation to separate object and background using Otsu methods. The objects images that had been separated are transformed into a binary image and grayscale image for feature extraction process. Texture features are extracted using Power LBP (PLBP) method and grayscale image as input. Shape features are extracted using Fourier Descriptor (FD) method and binary image as input. The results of these two features will be combined by considering the weight of each feature and then normalized. Combines texture features and shape features, we expect to obtain significant features that can improve the accuracy of classification. Tests was performed on three types of shells dataset that is blood clams, mussels and scallops feather sand by using SVM cross validation with $k=2$ fold. The results show that there is a link between features combine texture and shape features on the image classification problems that can be solved with the results obtained classification accuracy of $99.39 \%$ with a texture feature more dominant than the other features.

Keywords: Classification; feature extraction; Fourier Descriptor; Power LBP; Shellfish image.

\section{Pendahuluan}

$\mathrm{K}$ ERANG adalah hewan laut yang termasuk golongan hewan bertubuh lunak keluarga tiram, berinsang pipih dan berlapis, serta mempunyai sepasang cangkang yang dihubungkan dengan engsel, sehingga dapat dibuka dan ditutup. Kerang sendiri merupakan salah satu jenis moluska yang hasilnya melimpah di daerah tropis, salah satu sumber protein hewani yang baik dan murah bagi masyarakat. Kerang dan makanan yang berasal dari laut kaya akan asam amino dan asam lemak. Kerang dapat pula dikembangkan menjadi salah satu produk ekspor yang dapat diandalkan.

Contoh pada salah satu perusahaan yang bergerak dalam bidang industri pengolahan hasil perikanan laut seperti ikan, udang, rajungan dan kerang. Bahan mentah yang dikirimkan oleh nelayan atau distributor berupa ikan, udang, rajungan, dan kerang yang belum dipisahkan jenisnya. Sistem manual digunakan oleh pegawai pada bagian penerimaan (bongkar muat) untuk memisahkan jenis satu dengan jenis yang lainnya. Pemisahan secara manual ini bersifat subjektif karena sangat bergantung pada situasi, kondisi, dan keterampilan pegawai yang kemungkinan dapat menyebabkan kesalahan pemisahan. Bagi perusahaan, kesalahan pemisahan jenis dapat menyebabkan kegagalan di bagian produksi. 
Pemisahan secara otomatis (klasifikasi) dapat dilakukan dengan memanfaatkan teknologi komputer khususnya pengolahan citra (image processing). Salah satu bagian penting yang dapat mendukung keberhasilan proses klasifikasi adalah proses pengenalan pola. Proses pengenalan pola dilakukan dengan cara mengekstraksi fitur dari pola yang sudah ada. Fitur yang digunakan untuk mengenali pola cangkang kerang adalah fitur tekstur dan fitur bentuk. Fitur tekstur dapat mendeskripsikan susunan intensitas dari sekumpulan piksel-piksel yang bertetangga pada citra. Fitur bentuk dapat mendeskripsikan berdasarkan batas (boundarybased) dan berdasarkan daerah (region-based). Oleh karena itu, dibutuhkan metode ekstraksi fitur tekstur dan bentuk yang tepat agar dapat mencapai hasil akurasi yang tinggi pada proses klasifikasi.

Salah satu metode ekstraksi fitur tekstur yang baik adalah Local Binary Pattern (LBP). LBP adalah metode yang sederhana namun cukup efisien dalam merepresentasikan fitur tekstur [1]. LBP didefinisikan sebagai ukuran gray-scale invarian, tidak terpengaruh pada pencahayaan yang tidak merata pada sebuah citra, karena LBP mendeskripsikan tekstur secara lokal. Variasi dari LBP ada beberapa macam yakni LBP rotation invariant (LBPri) diusulkan oleh [2] untuk memperbaiki kinerja dari LBP. Completed Local Binary Pattern (CLBP) yang digunakan pada dataset Outex dan CuRET diusulkan oleh [3] hasil dari penelitian ini menunjukkan bahwa CLBP dapat meningkatkan nilai akurasi dibandingkan dengan LBP. Perbaikan CLBP yakni Completed Robust Local Binary (CRLBP) digunakan oleh [4]. Salah satu pengembangan terbaru dari metode LBP yakni Power LBP (PLBP) dikenalkan pada penelitian untuk mendeteksi senyum pada wajah yang gunanya untuk meningkatkan kinerja operator LBP dengan cara mendefinisikan skema perhitungan baru berdasarkan perbedaan intensitas mutlak [5]. Dalam penelitian ini metode PBLP dipilih menjadi metode yang digunakan untuk mengekstraksi fitur tekstur dikarenakan adanya pengaruh dari pemberian "power value $(\gamma)$ " yang memberikan pengaruh perubahan pencahayaan dan noise, sehingga mendapat hasil ekstraksi fitur tekstur yang optimal untuk proses klasifikasi.

Bentuk sebuah objek dapat direpresentasikan dalam dua kategori, yaitu berdasarkan region dan berdasarkan kontur. Metode yang digunakan pada representasi berbasis region adalah deskriptor moment pada penelitian yang dilakukan oleh [6], sedangkan representasi berbasis kontur melihat sebuah objek berdasarkan tepi dari bentuk objek tersebut. Penelitian yang dilakukan oleh [7] dengan menggunakan objek ikan berdasarkan bentuk, deskriptor yang digunakan berbasis region yang diambil dari moment invariant dan digabungkan dengan berbasis kontur menggunakan Simple Shape Descriptor (SSD). Tidak hanya SSD pada penelitian [8] menggunakan metode shape signature dan spectral descriptor. Shape signature merupakan representasi lokal dari fitur bentuk dan sangat sensitive terhadap noise. Hal ini memerlukan perbaikan yang lebih baik salah satunya menggunakan spectral transform seperti fourier descriptror atau wavelet transform. Fourier Descriptor (FD) adalah salah satu teknik yang popular untuk analisis dan deskripsi bentuk. Pada penelitian [9] sudah membuktikan adanya nilai akurasi yang lebih baik pada FD dibandingkan dengan pendekatan berbasis region. Penelitian berdasarkan deskriptor bentuk yang lain juga dilakukan oleh [10] untuk klasifikasi citra daun menggunakan FD, hasil penelitian ini menunjukkan nilai akurasi klasifikasi yang cukup baik. Oleh karenanya pada penelitian ini metode FD dipilih menjadi metode yang digunakan untuk mengekstraksi fitur bentuk dikarenakan beberapa penelitian sebelumnya yang menggunakan metode tersebut dan mendapatkan nilai akursi yang cukup baik, sehingga diharapakan mendapat hasil ekstraksi fitur bentuk yang optimal untuk proses klasifikasi.

Support Vector Machine (SVM) adalah salah satu teknik klasifikasi data dengan proses pelatihan (supervised learning). SVM dipilih karena kelebihannya dalam hal generalisasi. Salah satu ciri dari metode klasifikasi SVM adalah menemukan hyperplane terbaik sehingga diperoleh ukuran margin yang maksimal. Margin adalah jarak antara hyperplane tersebut dengan titik terdekat dari masing-masing kelas. Titik yang paling dekat ini disebut dengan support vector. Dengan pembelajaran terarah ini akan diperoleh fungsi yang menggambarkan bentuk ketergantungan input dan output. Selanjutnya, diharapkan fungsi yang diperoleh mempunyai kemampuan generalisasi yang baik, dalam arti bahwa fungsi tersebut dapat digunakan untuk data input di luar data pembelajaran. Klasifikasi citra menggunakan SVM juga pernah dilakukan oleh Ruiz, dkk, dalam mengklasifikasikan citra dermoscopy [11].

Pada penelitian ini mengusulkan kombinasi fitur tekstur dan fitur bentuk dalam klasifikasi citra kerang. Untuk mengekstraksi fitur tekstur menggunakan metode Power LBP, untuk mengekstraksi fitur bentuk menggunakan fourier descriptor dan SVM digunakan sebagai classifier-nya. Diharapkan kombinasi fitur tekstur dan bentuk tersebut bisa memberikan akurasi yang baik pada klasifikasi citra kerang.

\section{Tinjauan Pustaka}

\section{A. Kerang}

Kerang merupakan jenis invertebrate, yaitu hewan bertubuh lunak (Mollusca) kelas Bivalvia yang dagingnya tersembunyi di balik sepasang cangkangnya yang keras. Secara umum bagian tubuh kerang dibagi 
menjadi lima, yaitu (1) Kaki (foot byssus); (2) Kepala (head); (3) Bagian alat pencernaan dan reproduksi (visceral mass); (4) Selaput (mantle) dan (5) Cangkang (shell) [10]. Kerang merupakan sumber protein hewani yang lengkap. Mengandung semua jenis asam amino esensial yang dibutuhkan tubuh. Asam amino esensial adalah asam amino yang tidak dapat dibuat di dalam tubuh, sehingga mutlak harus berasal dari makanan. Yang termasuk dalam kelompok asam amino esensial adalah: Isoleusin, leusin, lisin, metionin, fenilalanin, treonin, triptofan dan valin.

Untuk dataset yang digunakan dalam penelitian ini mengambil jenis kerang yang umumnya dikonsumsi dan sering dijumpai disekitar pesisir pantai Laut Jawa. Ada tiga jenis kerang yang digunakan yakni kerang darah, kerang pasir dan kerang bulu. Pertama, kerang darah (anadara granosa) yang memiliki tekstur permukaan kasar dan beraturan, terdapat garis-garis rapi saling bertemuan berbentuk persegi kecil yang menonjol pada seluruh bagian cangkang. Kedua, kerang pasir (anadara polii) yang memiliki tekstur permukaan kasar dan beraturan, terdapat garis-garis rapi yang melingkar dan menonjol pada cangkang. Ketiga, kerang bulu (anadara antiquata) memiliki tekstur yang hampir sama dengan kerang pasir, namun corak yang terdapat lebih rapi dan sempit serta adanya bulu yang menutupi sebagian dari cangkang.

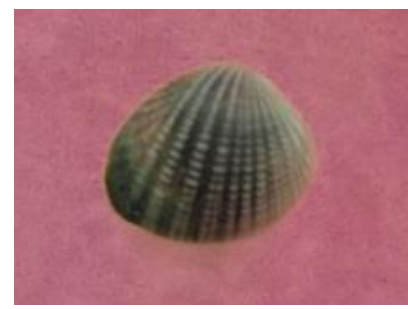

(a)

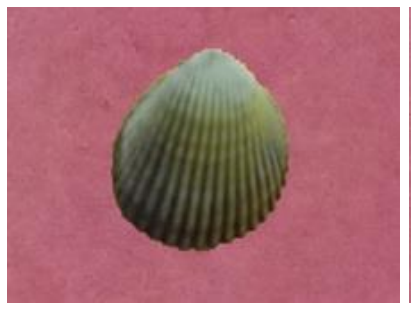

(b)

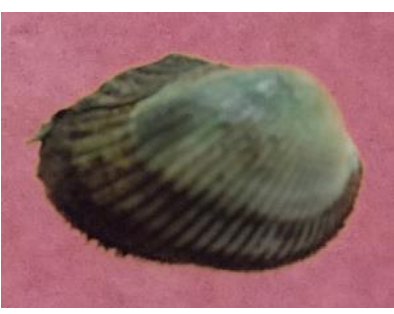

(c)

Gambar 1. Contoh Dataset. (a). Kerang Darah; (b). Kerang Pasir dan (c). Kerang Bulu.

\section{B. Fitur Tekstur}

Local Binary Pattern (LBP) adalah metode analisis ciri tekstur yang menggunakan model statistika dan struktur. LBP menganalisis tekstur secara lokal pada domain spatial, dengan membandingkan intensitas piksel antara piksel pusat dengan piksel-piksel tetangganya pada radius tertentu. Sehingga informasi gradien yang dapat diperoleh untuk merepresentasikan tepi, titik, dan ciri lokal lainnya dari sebuah citra. PLBP merupakan perkembangan dari metode Local Binary Pattern (LBP), sehingga PLBP memiliki ide dasar yang sama dengan LBP dalan hal mengekstraksi ciri tekstur. Ide dasarnya yaitu tekstur digambarkan secara lokal berdasarkan intensitas piksel pusat. PLBP menambah "power" atau yang disebut "D values". Dalam perhitungan intensitas piksel seperti yang ditunjukkan pada Persamaan (1) dari hasil tersebut, kemudian akan merubah nilai intensitas tiap pixel. $D$ values merupakan nilai citra yang telah mendapatkan " power" pada PLBP. Untuk $D_{x_{i}}$ adalah nilai satuan piksel yang akan dihitung pada Persamaan 1 dengan menentukan nilai $\gamma=1$.

$D_{x_{i}}=\sum_{k=0}^{P}\left|I\left(x_{i}\right)-I\left(x_{k}\right)\right|^{\gamma}, \quad i=0,1, \ldots, n-1$

Dengan adanya penambahan perhitugan untuk mendapatkan nilai "power" pada PLBP hal yang dilakukan berikutnya adalah menentukan rangking pada nilai intensitas pixel yang sudah mengalami perubahan. Prosedur urutan perangkingan pixel diperoleh dari perbedaan jumlah nilai absolute antar pixel yang telah didapatkan pada perhitungan Persamaan (1). Setelah perangkingan didapatkan, kemudian menentukan nilai PLBP, didasarkan pada nilai-nilai skala abu-abu dari intensitas pixel. Di mana pixel pusat yang telah melalui perangkingan menjadi acuan untuk pemberian nilai 0 dan 1 pada ketetanggan disekitar pixel tersebut seperti yang ditunjukkan pada Persamaan 2. Dan ilustrasi proses dari metode power LBP dapat dilihat pada Gambar 2.

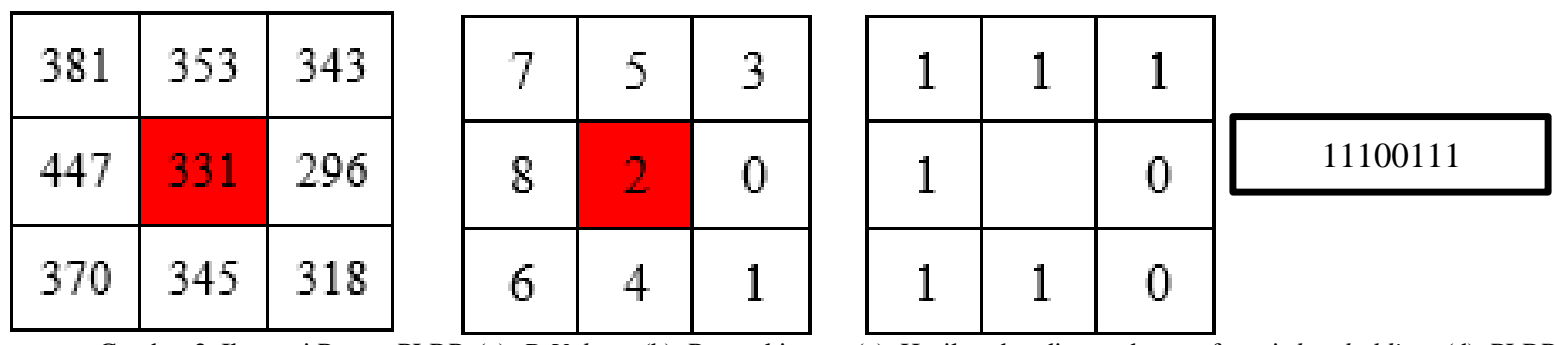

Gambar 2. Ilustrasi Proses PLBP. (a). D Values; (b). Perangkingan; (c). Hasil perbandingan dengan fungsi thresholding; (d). PLBP 
$P L B P_{P, R}\left(x_{0}\right)=\sum_{k=1}^{\mathrm{P}-1} s\left(D x_{k}-D x_{0}\right) 2^{P}$

\section{Fitur Bentuk}

Bentuk direpresentasikan dalam 2 kategori, yaitu berdasarkan region dan berdasarkan kontur. Untuk representasi berdasarkan region, piksel yang berada di dalam area objek dihitung untuk memperoleh representasi bentuk. Metode yang sering digunakan adalah deskriptor moment. Representasi moment pada region merupakan fungsi graylevel citra yang dinormalisasi sebagai probability density dari variabel random 2D. Moment memiliki fitur yang bersifat global sehingga informasi mengenai representasi kontur masih kurang.

Representasi berdasarkan kontur hanya melihat informasi dari tepi bentuk. Metode representasinya dapat dikategorikan menjadi global shape descriptor, shape signature dan spectral descriptor. Deskriptor global seperti area, circularity, eccentricity dan axis orientation digunakan untuk membedakan bentuk dengan tingkat ketidaksamaan yang besar, yang biasanya digunakan untuk tujuan filtering. Representasi bentuk menggunakan shape signature membutuhkan komputasi yang tinggi pada proses perhitungan similarity. Representasi menggunakan spectral descriptor memerlukan pengolahan lebih lanjut menggunakan transformasi spectral seperti transformasi fourier dan wavelet yang diperoleh dari shape signature. Cara ini menjadi pilihan yang terbaik untuk kasus klasifikasi dengan bentuk obyek yang mirip.

FD sukses diaplikasikan untuk merepresentasikan suatu bentuk citra. FD diperoleh dari fourier transform dari shape signature. FD tidak hanya mengatasi kelemahan deskriptor moment dan deskriptor global untuk kemampuannya dalam membedakan, tetapi juga mengatasi noise sensitivity pada shape signature. Kelebihan lain pada FD adalah mudah dalam melakukan normalisasi (pencocokan) dan compact.

Sebelum mengaplikasikan FD pada shape signature, titik tepi harus diambil sampel dengan jumlah yang tetap. Umumnya setiap obyek pada gambar yang berbeda memiliki jumlah titik tepi yang berbeda. Untuk keperluan klasifikasi, jumlah titik tepi yang diambil dari data training harus sama dengan data testing. Pengambilan sampling ini akan menormalisasi jumlah titik tetapi juga memberikan efek smoothing pada bentuk. Terdapat 3 metode normalisasi, yaitu (1) Equal points sampling; (2) Equal angle sampling dan (3) Equal arclength sampling.

\section{Support Vector Machine (SVM)}

Support Vector Machine (SVM) termasuk model pembelajaran terarah (supervised learning) yang dikaitkan dengan analisis data dan pengenalan pola, digunakan juga untuk klasifikasi dan analisis regresi. Teknik SVM digunakan untuk menemukan fungsi pemisah (classifier) optimal yang bisa memisahkan dua dataset data dari dua kelas yang berbeda. Penggunaan teknik machine learning tersebut, karena kualitas yang meyakinkan dalam memprediksi sebuah kelas untuk suatu data baru. Salah satu contoh classifier atau bidang pemisah yang biasa disebut hyperplane ditunjukkan pada Gambar 3. Pada Gambar 3 ditunjukkan dua buah kelas yang dipisahkan dengan linear hyperplane sebagai bentuk yang paling sederhana pada SVM. Sebagai acuan, terdapat training set $D$ yang dapat dinotasikan dengan pada Persamaan 3.

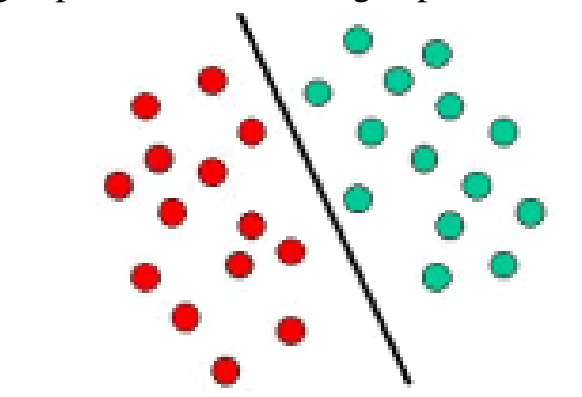

Gambar 3. Dua buah kelas terpisah dengan hyperplane

$$
D=\left\{\left(x_{i,} y_{i}\right) \mid x_{i} \in R^{p}, y_{i} \in\{-1,1\}\right\}
$$

Terkadang dalam beberapa kasus terdapat beberapa data latih yang kurang baik atau terpisah dari yang lain baik karena sifatnya maupun nilai dari datanya. Kasus seperti ini biasa disebut non-separable case. Kasus ini menyebabkan dua buah ruang masukan tidak dapat terpisahkan dengan sempurna sehingga pembentukan decision boundary dari kasus membutuhkan soft margin. Soft margin ini dapat menjadi toleransi data-data yang error tersebut sementara margin yang sebenarnya membentuk bidang/plane yang maksimum.

Dalam mengerjakan nonlinier SVM adalah mentransformasikan data dari ruang koordinat awal $x$ menjadi ruang baru dengan fungsi $\emptyset(x)$ sehingga membentuk sebuah barisan linier yang dapat digunakan 
untuk memisahkan data-data yang diinginkan. Hal ini diterapkan agar selanjutnya dapat dilakukan metode pencarian batas bidang seperti pada proses linier SVM sebelumnya. Hal ini sejalan dengan teori Cover yang menyatakan "Jika suatu tarnsformasi bersifat non linier dan dimensi dari feature space cukup tinggi, maka data pada input space dapat dipetakan ke feature space yang baru, di mana pattern-pattern tersebut pada probabilitas tinggi dapat dipisahkan secara linier".

Ilustrasi dari konsep ini dapat dilihat pada Gambar 4. Pada Gambar 4 diperlihatkan input space pada data kelas hijau dan data kelas merah tidak dapat dipisahkan secara linier.

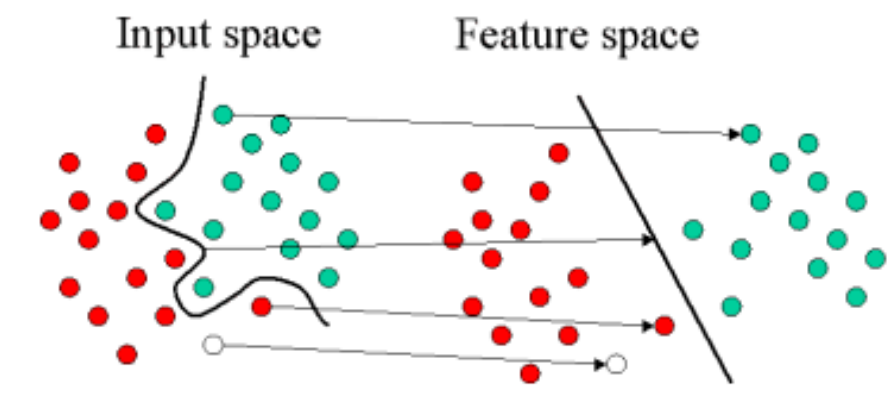

Gambar 4. Ilustrasi hyperplane pada nonlinier SVM

Kernel trick memberikan berbagai kemudahan dalam proses pembelajaran SVM karena untuk menentukan support vector, fungsi kernel kita hanya perlu mengetahui fungsi kernel yang dipakai dan tidak perlu mengetahui wujud dari fungsi non linier $\emptyset$. Beberapa jenis kernel yang sering dipakai ditunjukkan pada Tabel 1.

TABEL I

KERNEL YANG UMUM DIPAKAI DALAM SVM

\begin{tabular}{ll}
\hline \multicolumn{1}{c}{ Jenis Kernel } & \multicolumn{1}{c}{ Formula } \\
\hline Linear & $K\left(x_{i}, x_{j}\right)=x_{i} \cdot x_{j}$ \\
Radial Basis Function (RBF)/ & $K\left(x_{i}, x_{j}\right)=\exp \left(-\frac{\left\|x_{i}-x_{j}\right\|^{2}}{2 \sigma^{2}}\right)$ \\
Gaussian & $K\left(x_{i}, x_{j}\right)=\left(x_{i} \cdot x_{j}+1\right)^{p}$ \\
Polynomial & $K\left(x_{i}, x_{j}\right)=\tanh \left(\alpha x_{i} \cdot x_{j}+\beta\right)$ \\
Sigmoid &
\end{tabular}

III. METODE

Secara garis besar ada dua alur pada penelitian ini, yaitu proses pelatihan dan proses uji coba. Pada proses pelatihan dan uji coba memiliki tiga tahapan utama, di mana tahapan pertama adalah proses awal, tahapan kedua adalah ekstraksi fitur, dan tahapan ketiga adalah klasifikasi.

\section{A. Proses Awal}

Suatu citra, sebelum mengalami proses lebih lanjut perlu dilakukan tahap praproses (preprocessing), yaitu teknik yang digunakan untuk mempersiapkan suatu citra agar dapat menghasilkan keluaran yang diinginkan. Citra yang telah melalui tahapan preprocessing, kemudian akan melalui tahapan segmentasi, yakni pemisahan antara foreground dan obyek. Pada penelitian ini citra asli melalui tahapan praproses yakni merubah citra asli dalam bentuk citra RGB, selanjutnya pemrosesan citra dilakukan dengan merubah citra RGB menjadi citra grayscale dan kemudian dilakukan proses deteksi tepi canny, dilasi dan proses median filtering. Tahapan proses tersebut untuk mendapatkan bentuk tepi cangkang (citra biner) yang selanjutnya akan diproses pada saat ekstraksi fitur bentuk. Untuk tahapan selanjutnya, citra grayscale melalui deteksi tepi canny yang digunakan untuk mendapatkan tepi dari obyek. Proses dilasi dan erosi pada citra juga digunakan pada tahap ini, selanjutnya dilakukan proses skeleton yang digunakan untuk mereprsentasikan bentuk citra biner dari objek kerang.

\section{B. Ekstraksi Fitur}

Ada dua jenis fitur yang digunakan dalam penelitian ini yaitu fitur tekstur dan fitur bentuk. Fitur tekstur diekstraksi meggunakan metode PLBP. Citra grayscale dengan obyek yang sudah disegmentasi dijadikan input untuk proses ekstraksi fitur tekstur dapat dilihat pada Gambar 5.

Tahapan untuk mendapatkan fitur tekstur antara lain:

1. Pemberian nilai "power" atau $D$ values

Pada proses ini citra mengalami perubahan nilai intensitas dari nilai citra asli menjadi nilai $D$ values dengan menggunakan Persamaan (1).

2. Perangkingan 
Prosedur urutan pemeringkatan piksel diperoleh dari perbedaan jumlah nilai absolute antar piksel, di mana nilai intensitas pikel terkecil mendapat rangking ke-0 dan rangking seterusnya mengikuti jumlah ketetanggaan piksel.

3. Perbandingan dengan nilai threshold.

Prosedur pemberian nilai biner 0 dan 1 untuk threshold mengacu pada piksel pusat, bila urutan piksel tetangga lebih besar dari piksel pusat maka nilai yang diberikan adalah satu dan begitu sebaliknya.

4. Menentukan nilai histogram fitur

Untuk nilai histogram dapat dihitung secara matematika, histogram dapat didefinisikan dengan Persamaan (4).

$H_{j}=\sum_{x, y}^{L-1} I(x, y)=j, \quad j=0,1, \ldots, n-1$

$H_{j}$ adalah nilai histogram pada intensitas ke- $j, I(x, y)$ adalah nilai intensitas pada koordinat piksel $(x, y)$, $L$ adalah ukuran jumlah piksel pada suatu citra, dan $n$ adalah nilai maksimal intensitas.

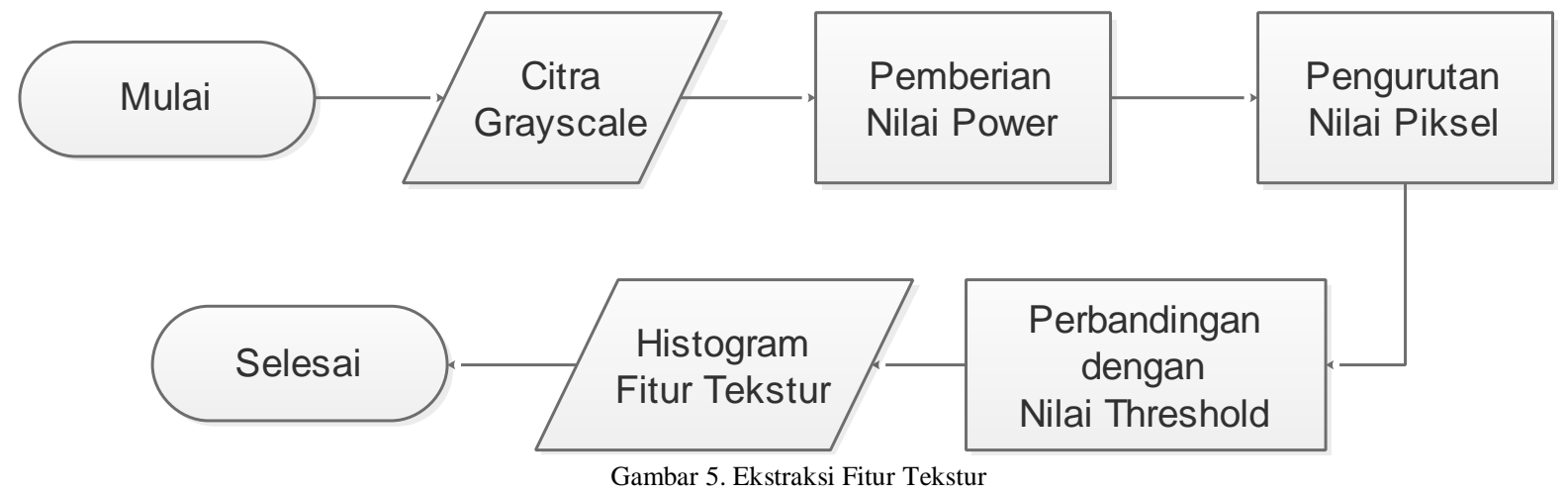

Fitur bentuk diekstraksi menggunakan metode Fourier Descriptor. Citra biner dengan objek yang sudah disegmentasi dijadikan input untuk proses ekstraksi deskriptor bentuk pada citra dapat dilihat pada Gambar 6 .

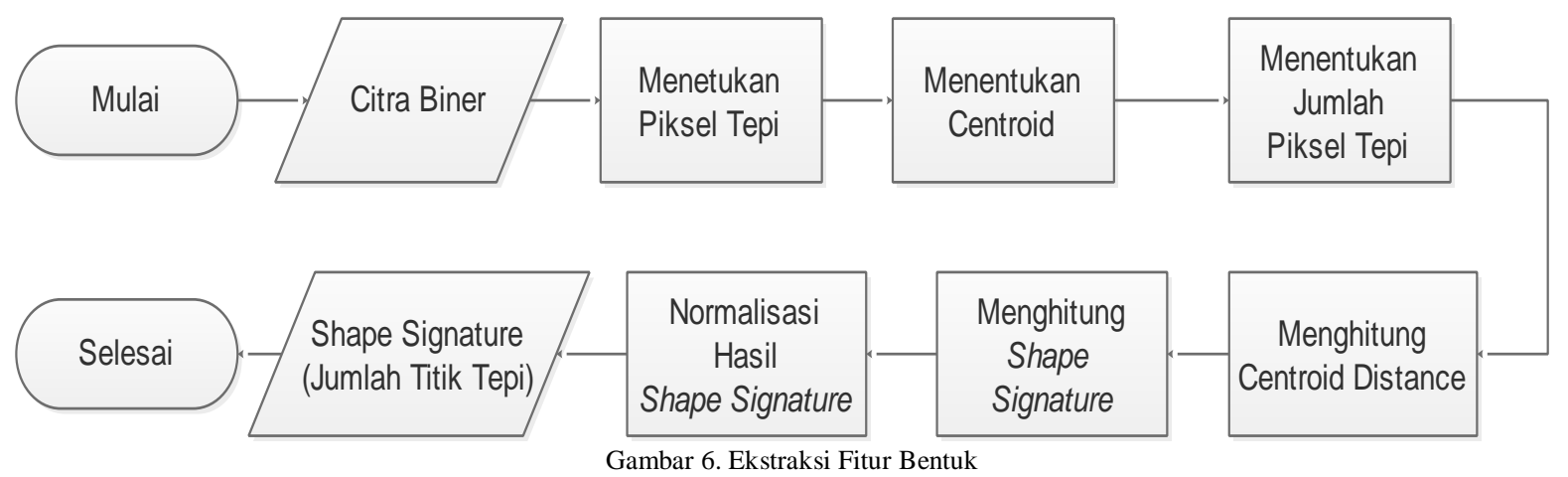

Tahapan untuk mendapatkan deskriptor bentuk antara lain:

1. Menentukan piksel tepi

Pada proses ini menggunakan algoritma boundary tracing.

2. Menentukan centroid

Piksel centriod diperlukan untuk menghitung centroid distance.

3. Menentukan jumlah titik tepi yang tepat

Proses klasifikasi memerlukan jumlah fitur yang tetap. Untuk citra yang berbeda akan menghasilkan segmentasi yang berbeda dengan jumlah titik tepi yang berbeda. Sehingga diperlukan penetapan jumlah titik tepi agar semua data training dan data testing memiliki dimensi yang sama. Penentuan titik tepi dilakukan dengan metode equal arclength sampling untuk menentukan jarak kandidat titik berikutnya yang menggunakan Persamaan (5).

$\mathrm{x}^{\prime}=\frac{P}{K}$

Kandidat titik berikutnya $x^{\prime}$ diperoleh dari hasil perbandingan perimeter tepi bentuk $P$ dengan jumlah titik yang ditentukan $K$. 
4. Mengitung centroid distance

Centroid distance merupakan shape signature yang digunakan oleh FD di penelitian ini. Jarak dihitung dari titik centroid dengan titik tepi yang sudah ditentukan.

5. Menghitung Shape Signature

Shape Signature pada FD dihitung pada setiap jarak dengan menggunakan Persamaan (6).

$a_{n}=\frac{1}{N} \sum_{t=0}^{N-1} s(t) \exp \left(\frac{-j 2 \pi n t}{N}\right), \mathrm{n}=0,1, \ldots, \mathrm{N}-1$

Magnitude koefisien $a_{n}(n=0,1, \ldots, N-1)$ yang dinormalisasi oleh magnitude koefisien pertama digunakan sebagai shape descriptor.

6. Menormalisasi Shape Signature

Koefisien pertama digunakan untuk menormalisasi semua koefisien yang dirumuskan pada Persamaan (7).

$s(n)=\left|\frac{a_{n}}{a_{0}}\right|, n=0, \ldots, N-1$

Magnitude koefisien pertama a digunakan sebagai shape descriptor yang disebut Fourier descriptor dan nilai koefisien yang sudah dinormalisasi merupakan nilai fitur bentuk.

\section{Kombinasi Fitur}

Pada tahap ini dilakukan proses penggabungan atau kombinasi antara ekstraksi fitur tekstur dan fitur bentuk. Untuk ekstraksi fitur tekstur akan didapatkan nilai dari histogram fitur yang dihasilkan dan akan dilakukan pengujian dengan kuantisasi panjang histogram, sedangkan untuk ekstraksi fitur bentuk didapatkan nilai dari shape signature pada FD yang berupa jumlah titik tepi dan akan dilakukan pengujian dengan jumlah titik tepi yang berbeda-beda. Hasil dari kedua fitur tersebut akan dikombinasikan, kemudian dianalisa untuk melihat tingkat signifikansinya. Selanjutnya dilakukan pula proses pembobotan untuk normalisasi.

\section{Klasifikasi}

Pada tahap klasifikasi dilakukan dengan menggunakan Support Vector Machine (SVM). Meskipun pada awalnya SVM merupakan pengklasifikasi untuk dua kelas saja, dalam pengembangannya SVM tidak hanya melakukan klasifikasi untuk dua kelas saja melainkan lebih dari dua kelas (multiclass). Alasan menggunakan pengklasifikasi ini adalah karena kemampuan dalam generalisasi, implementasi yang relatif mudah, serta kemampuannya dalam menangani data berdimensi tinggi [12]. Dalam tahap klasifikasi ada beberapa percobaan kernel yang dilakukan yakni kernel linear, kernel Radial Basis Function (RBF)/Gaussian dan kernel Polynomial.

\section{Hasil UJi COBA Dan ANALisa}

\section{A. Lingkungan Uji Coba}

Uji coba pada penelitian ini, spesifikasi dari perangkat keras yang digunakan dalam implementasi perangkat lunak terdiri atas processor Intel Core i3 $2.20 \mathrm{G.Hz}$, memori berkapasitas $2.00 \mathrm{~GB}$ dan harddisk dengan kapasitas sebesar 500 GB. Sedangkan untuk spesifikasi perangkat lunak yang digunakan dalam implementasi perangkat lunak yakni Microsoft Excel dan Matlab R2013a.

\section{B. Data Uji Coba}

Pada penelitian ini, dataset yang digunakan adalah citra RGB yang berukuran $300 \times 225$. Jumlah dataset yang digunakan sebagai data uji coba adalah sebanyak 60 citra kerang, terdiri dari 3 kelas/spesies yang berbeda, yaitu 20 citra kerang darah, 20 citra kerang pasir dan 20 citra kerang bulu. Pengambilan dataset diambil secara pribadi oleh peneliti pada pagi hari dengan pencahayaan yang cukup baik. Kerang yang dijadikan dataset merupakan kerang konsumsi yang masih segar.

\section{Skenario Uji Coba} berikut:

Skenario uji coba pada penelitian ini dibagi ke dalam tiga skenario, yaitu skenario 1, 2 dan 3 sebagai

1. Pengujian fitur tekstur

Pada skenario uji coba, proses ini dilakukan untuk pengujian klasifikasi citra kerang berdasarkan fitur tekstur dengan mengkuatisasi hasil histogram fitur tekstur yakni histogram 256 fitur, 128 fitur, 64 fitur dan 32 fitur. Hasil dari kuantisasi histogram dapat dilihat melalui nilai histogram fitur yang memiliki 
hasil akurasi klasifikasi yang paling baik.

2. Pengujian fitur bentuk

Pada skenario uji coba, proses ini dilakukan pengujian klasifikasi berdasarkan fitur bentuk dengan penentuan jumlah titik tepi yang berbeda-beda. Hasil dari fitur bentuk ini dilihat dari jumlah titik tepi yang memiliki nilai akurasi klasifikasi yang paling baik.

3. Kombinasi fitur

Pada skenario uji coba, proses ini dilakukan pengujian klasifikasi yang mengkombinasikan fitur tekstur dan fitur bentuk. Nilai $\alpha$ dan $\beta$ diberikan pada fitur tekstur dan fitur bentuk sehingga memperoleh fitur kombinasi seperti yang dirumuskan pada Persamaan 8 .

\section{Fitur Kombinasi $=\alpha$ [fitur tekstur $] \beta[$ fitur bentuk $]$}

Uji coba yang akan dilakukan adalah melihat nilai akurasi klasifikasi apabila nilai kedua fitur dikombinasikan. Akurasi klasifikasi diperoleh dengan menggunakan Persamaan 9.

$$
\text { akurasi }=\frac{\text { Jumlah klasifikasi benar }}{\text { Jumlah dataset }} \times 100 \%
$$

\section{Uji Coba}

Pada penelitian ini, terdapat beberapa tahapan yang dilakukan untuk memperoleh citra keluaran berupa tekstur dan bentuk kerang yang diharapkan . Pada Gambar 7 menunjukkan hasil dari tahapan praproses untuk memperoleh citra yang akan digunakan pada tahapan selanjutnya.

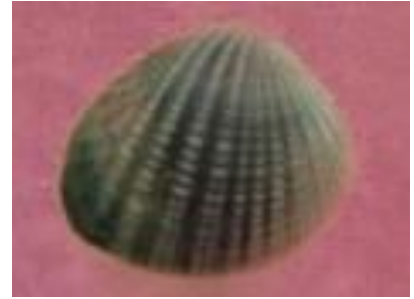

(a)

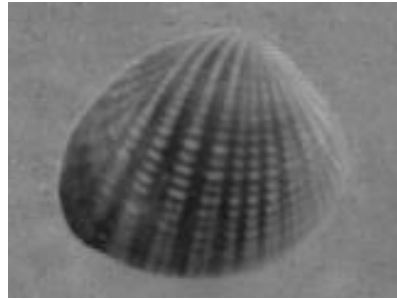

(b)

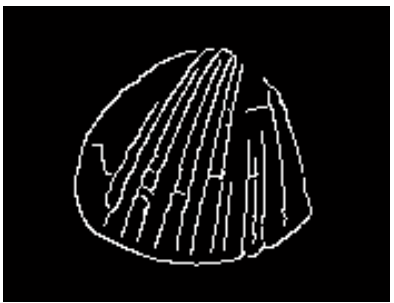

(c)

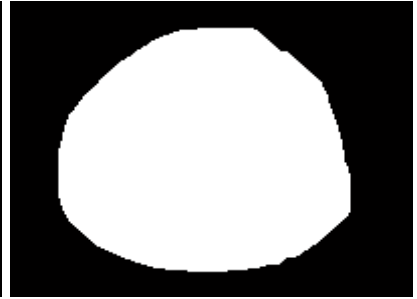

(d)

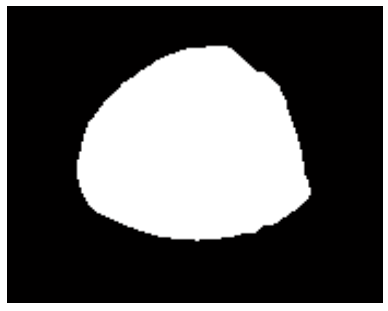

(e)

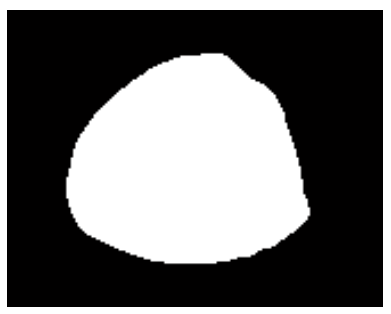

(f)

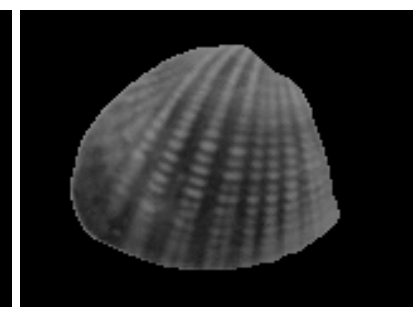

(g)

Gambar 7. Tahap praproses citra. (a). Citra asli; (b). Citra grayscale; (c). Citra biner; (d). Citra hasil dilasi; (e). Citra hasil erosi; (f). Citra hasil median filtering; (g). Hasil penggabungan citra grayscale.

Untuk pengujian hasil klasifikasi fitur tekstur dilakukan terhadap citra kerang pada dataset yang ada. Pengujian klasifikasi ini dengan perbandingan 50:50, yakni menggunakan setengah dari dataset sebanyak 30 citra sebagai data uji dan 30 citra sebagai data latih. Menggunakan SVM cross validation 2-fold. Dari hasil klasifikasi inilah diketahui nilai akurasi klasifikasi dari masing-masing histogram, mulai dari histogram fitur asli yang memiliki panjang 256 fitur dan yang mengalami kuantisasi histogram yakni 128 fitur, 64 fitur, dan 32 fitur dapat dilihat pada Gambar 8.

Uji coba kedua pada pengujian fitur bentuk dengan menggunakan metode fourier descriptor. Ekstraksi fitur bentuk pengujian awalnya dimulai dengan mengekstraksi titik-titik tepi dan menentukan titik centroid pada tiap citra yang ada. Jumlah titik-titik tepi yang diperoleh setiap citra berbeda-beda. Untuk memudahkan proses klasifikasi maka diperlukan jumlah titik tepi yang sama pada semua dataset. Uji coba yang pertama pada ekstraksi fitur bentuk, titik tepi yang digunakan sebanyak jumlah titik tepi terkecil dari dataset. Selanjutnya titik-titik inilah yang digunakan dalam menghitung jarak centroid. Koordinat pertama yang diambil adalah titik yang letaknya pada $x$ dan $y$ minimum. Titik-titik tepi berikutnya ditentukan menggunakan Persamaan (5) yang berjalan searah jarum jam. Jarak titik tepi dan titik centroid inilah yang akan dijadikan shape signature pada Fourier Descriptor.

Pengujian yang dilakukan kemudian dengan menggunakan jumlah titik tepi yang berbeda-beda untuk melihat titik tepi mana yang memiliki nilai paling optimal sehingga mendapatkan nilai akurasi hasil klasifikasi 
yang paling baik. Berdasarkan beberapa kali pengujian dengan menggunakan 100 titik tepi sampai dengan nilai titik tepi 500. Dari hasil akurasi klasifikasi tersebut, jumlah titik tepi terbaik yang didapatkan adalah 198 titik tepi dengan nilai akurasi $72,72 \%$ dapat dilihat pada Gambar 9.

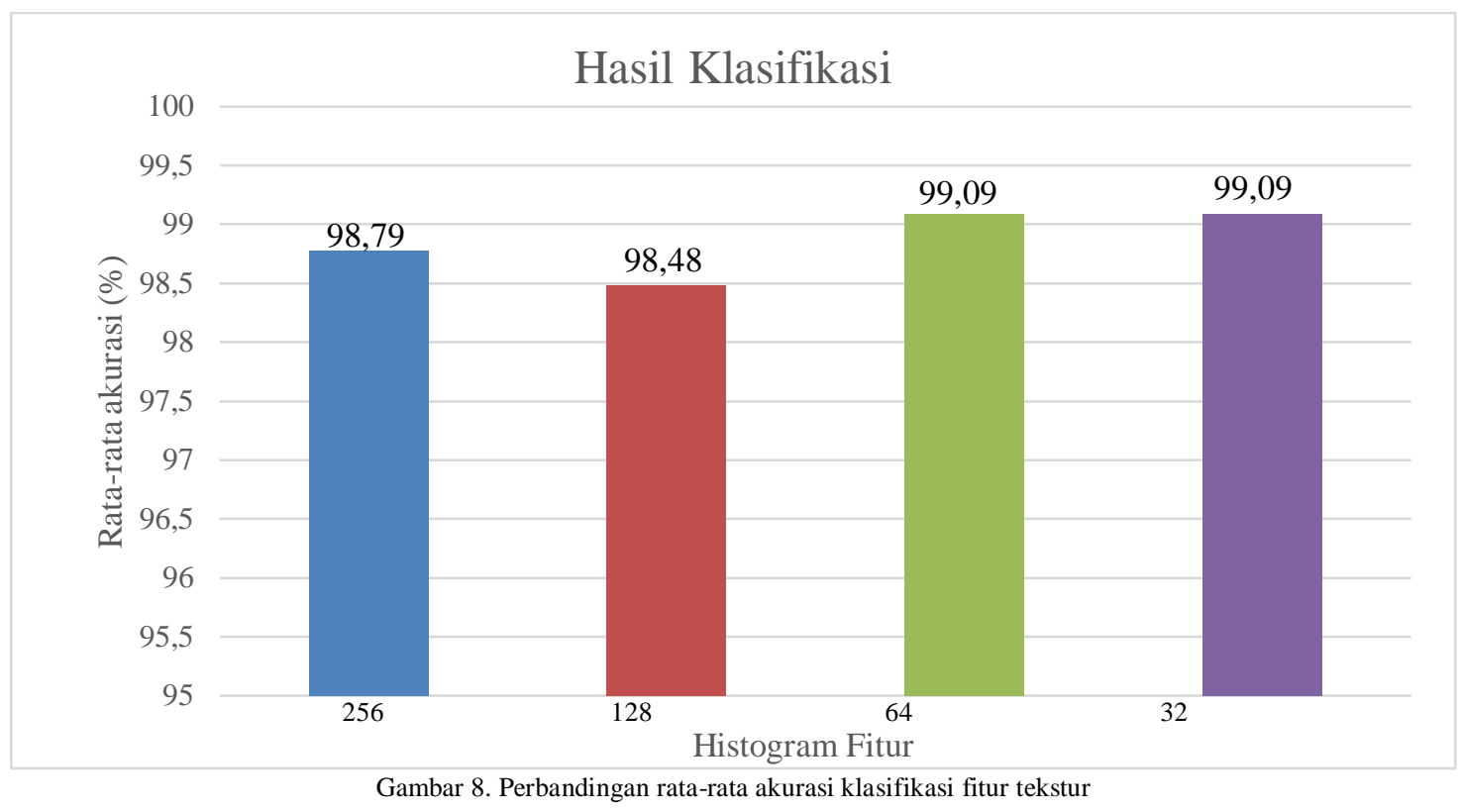

Uji coba kedua pada pengujian fitur bentuk dengan menggunakan metode fourier descriptor. Ekstraksi fitur bentuk pengujian awalnya dimulai dengan mengekstraksi titik-titik tepi dan menentukan titik centroid pada tiap citra yang ada. Jumlah titik-titik tepi yang diperoleh setiap citra berbeda-beda. Untuk memudahkan proses klasifikasi maka diperlukan jumlah titik tepi yang sama pada semua dataset. Uji coba yang pertama pada ekstraksi fitur bentuk, titik tepi yang digunakan sebanyak jumlah titik tepi terkecil dari dataset. Selanjutnya titik-titik inilah yang digunakan dalam menghitung jarak centroid. Koordinat pertama yang diambil adalah titik yang letaknya pada $x$ dan $y$ minimum. Titik-titik tepi berikutnya ditentukan menggunakan Persamaan (5) yang berjalan searah jarum jam. Jarak titik tepi dan titik centroid inilah yang akan dijadikan shape signature pada Fourier Descriptor.

Pengujian yang dilakukan kemudian dengan menggunakan jumlah titik tepi yang berbeda-beda untuk melihat titik tepi mana yang memiliki nilai paling optimal sehingga mendapatkan nilai akurasi hasil klasifikasi yang paling baik. Berdasarkan beberapa kali pengujian dengan menggunakan 100 titik tepi sampai dengan nilai titik tepi 500. Dari hasil akurasi klasifikasi tersebut, jumlah titik tepi terbaik yang didapatkan adalah 198 titik tepi dengan nilai akurasi $72,72 \%$ dapat dilihat pada Gambar 9.

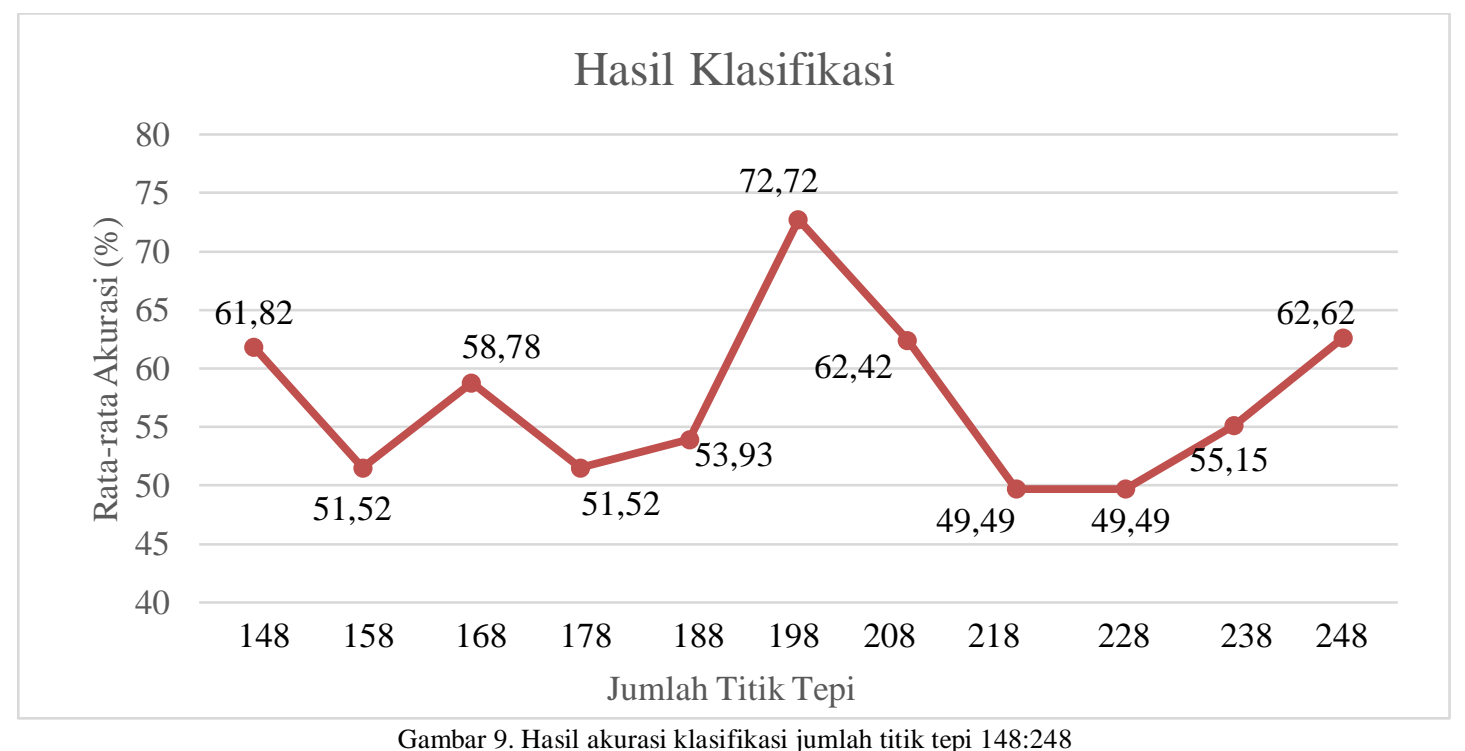

Uji coba ketiga yang dilakukan adalah pengujian untuk membuktikan bahwa ada keterkaitan kombinasi antara fitur tekstur dari area cangkang kerang dan fitur bentuk dari area pinggiran (tepi) cangkang kerang. Fitur yang menjadi masukan dalam uji coba ini adalah kombinasi dari fitur tekstur dan fitur bentuk yang diperoleh 
dari uji coba pertama dan uji coba kedua. Pada uji coba kombinasi fitur, nilai histogram yang didapat dari ekstraksi fitur tekstur dengan nilai histogram 256 fitur, 128 fitur, 64 fitur, dan 32 fitur. Masing-masing dari nilai histogram tersebut dikombinasikan dengan uji coba pada ektrasksi fitur bentuk yang telah menetapkan jumah titik tepi yang paling optimalnya adalah 198 titik tepi.

Sebelum proses kombinasi kedua fitur dilakukan, dilakukan proses normalisasi untuk salah fitur yang ada. Hasil nilai fitur bentuk mengalami perubahan range nilai antara 0-1, sedangkan nilai hasil fitur bentuk tidak mengalami normalisasi karena sudah dalam range nilai 0-1. Setelah kedua fitur memiliki range nilai yang sama kemudian proses kombinasi kedua fitur dilakukan. Uji coba kombinasi dilakukan dengan menentukan nilai bobot untuk masing- masing $\alpha$ dan $\beta$. Ketika nilai bobot sudah diberikan untuk masing-masing fitur kemudian dilakukan proses klasifikasi.

Pada Tabel 2 dapat dilihat telah dilakukan 4 kali pengujian dengan menentukan nilai bobot $\alpha$ dan $\beta$ yang beragam dengan hasil akurasi klasifikasi masing-masing yang telah didapatkan.

TABEL II

Hasil AKURasi Uji Bobot Kombinasi Fitur

\begin{tabular}{|c|c|c|c|c|}
\hline \multirow{2}{*}{ UJI BOBOT } & \multicolumn{4}{|c|}{ Histogram Kuantisasi } \\
\hline & 256 Fitur & 128 Fitur & 64 Fitur & 32 Fitur \\
\hline $\begin{array}{l}\alpha=2 \\
\beta=1\end{array}$ & $98,78 \%$ & $99.09 \%$ & $98.78 \%$ & $96.36 \%$ \\
\hline $\begin{array}{l}\alpha=1 \\
\beta=2\end{array}$ & $98.18 \%$ & $98.18 \%$ & $98.48 \%$ & $97.57 \%$ \\
\hline $\begin{array}{l}\alpha=2 \\
\beta=3\end{array}$ & $99.09 \%$ & $98.78 \%$ & $98.48 \%$ & $98.48 \%$ \\
\hline $\begin{array}{l}\alpha=3 \\
\beta=2\end{array}$ & $98.48 \%$ & & $98.18 \%$ & $98.98 \%$ \\
\hline
\end{tabular}

Pada Gambar 10 merupakan hasil akurasi klasifikasi dengan kuantisasi histogram 128 fitur, sesuai dengan hasil pada Tabel 2 yakni tabel hasil akurasi uji bobot kombinasi fitur dimana setelah melalui empat kali pengujian didapatkan hasil kombinasi terbaik ada pada histogram kuantisasi 128 fitur.

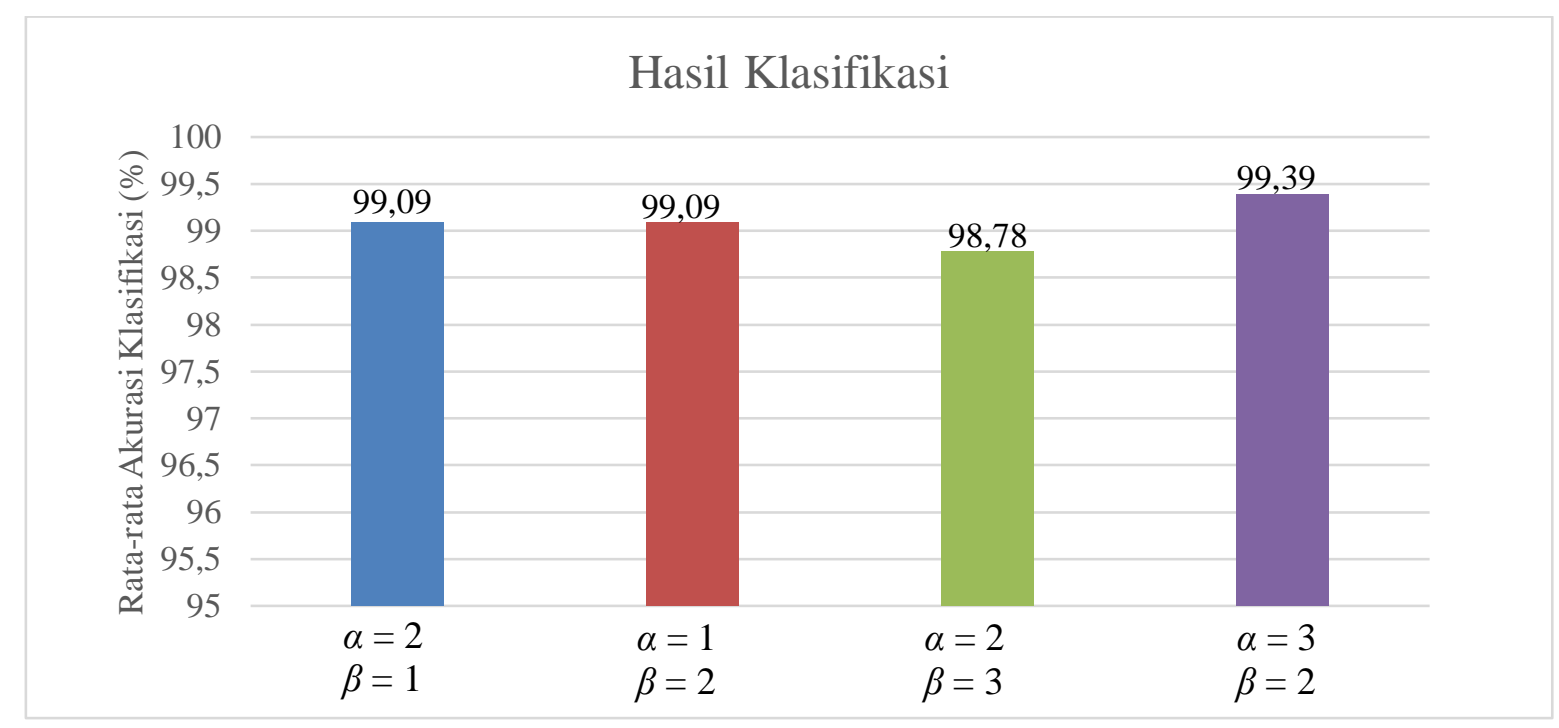

Gambar 10. Hasil Akurasi Klasifikasi dengan Kuantiasai Histogram Fitur 128

\section{E. Pembahasan}

Hasil pengujian skenario pertama yakni ekstraksi fitur tekstur dengan metode PLBP menggunakan perbandingan 50:50 antara data uji dan dan data latih, dapat dilihat nilai akurasi klasifikasi dari setiap histogram fitur tekstur. Adapun nilai akurasi klasifikasi dengan histogram 256 fitur yaitu $98.79 \%$, nilai akurasi klasifikasi dengan kuantisasi histogram 128 fitur yaitu 98.48\%, sedangkan nilai akurasi klasifikasi dengan kuantisasi histogram 64 fitur dan 32 fitur yaitu 99.09\%.

Hasil pengujian skenario kedua yakni ekstraksi fitur bentuk menunjukkan bahwa jumlah titik tepi sebanyak 198 memiliki akurasi klasifikasi yang paling tinggi yakni dengan nilai akurasi klasifikasi sebesar 
$72,72 \%$, dibandingkan dengan jumlah titik tepi yang lainnya. Hal ini karena pemilihan titik tepi sebanyak 198 dapat merepresentasikan bentuk yang cukup optimal dan dengan titik tepi tersebut, tepi bentuk kerang menjadi halus dan dapat merepresentasikan bentuk aslinya.

Pengujian kombinasi fitur tekstur dan fitur bentuk dilakukan dengan menetukan bobot untuk setiap fiturnya. Uji coba yang dilakukan pada proses kombinasi fitur menunjukkan bahwa memberikan bobot yang lebih tinggi pada fitur tekstur, maka hasil akurasi yang didapatkan akan semakin baik, sedangkan apabila memberikan bobot yang lebih tinggi pada fitur bentuk, maka hasil klasifikasi yang didapatkan tidak menunjukkan hasil yang signifikan terkadang hasil klasifikasi menjadi baik bisa juga hasil klasifikasi menjadi menurun. Hal ini menunjukkan bahwa fitur tekstur lebih dominan terhadap objek kerang dibandingkan fitur bentuk. Hasil akurasi klasifikasi yang paling baik yaitu histogram kuantisasi 128 fitur dengan pemberian nilai $\alpha$ dan $\beta$ untuk pembobotan kombinasi $\alpha=3$ dan nilai $\beta=2$. Nilai akurasi klasifikasi yang didapatkan adalah 99,39\% dapat dilihat pada Gambar 11, dibandingkan dengan histogram kuantisasi 128 fitur tanpa normalisasi.

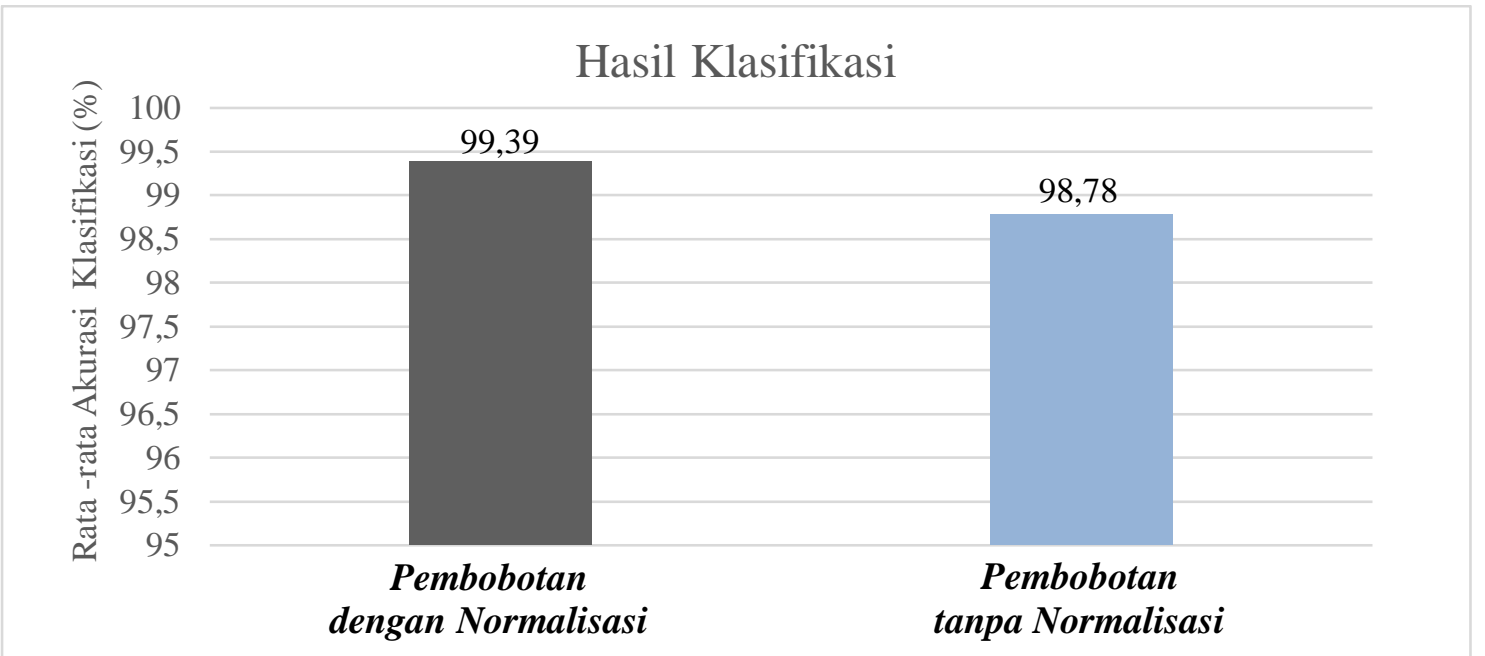

Gambar 11. Hasil akurasi klasifikasi kombinasi fitur tekstur dan bentuk dengan pembobotan dinormalisasi dan tidak dinormalisasi dengan histogram kuantisasi 128 fitur

\section{KESIMPULAN}

Dari hasil pengujian dan analisa pada penelitian ini, dapat diambil beberapa kesimpulan, diantaranya adalah:

a. Dengan menggunakan fitur tunggal pertama, yakni fitur tekstur didapatkan hasil akurasi klasifikasi yang baik yakni 99,09\%. Hal ini dapat dikatakan untuk ekstraksi fitur tekstur sudah cukup berhasil.

b. Dengan fitur tunggal kedua, yakni fitur bentuk didapatkan hasil akurasi klasifikasi sebesar 72,72\%. Pengujian fitur memiliki nilai akurasi klasifikasi yang kurang tinggi, hal ini dikarenakan bentuk dari tiap dataset yang memiliki kemiripan.

c. Proses kombinasi antara fitur tekstur dari tekstur cangkang kerang dan fitur bentuk dari pinggiran/bentuk kerang hasil akurasi klasifikasi bisa meningkat hingga 99,39\%. Adanya sedikit kenaikan dengan mengkombinasikan kedua fitur. Hal ini disebabkan bahwa terdapat keterkaitan antara kombinasi fitur tekstur dan fitur bentuk.

d. Hasil perbandingan pemilihan fitur menunjukkan bahwa fitur tekstur lebih dominan dibandingkan dengan fitur bentuk.

Adapun saran untuk penulis yang berguna untuk penelitian-penelitian selanjutnya, yaitu:

a. Mencoba mengkombinasikan kedua metode lain untuk ekstraksi fitur tekstur dan ekstraksi fitur bentuk. b. Perlu penambahan dataset untuk citra kerang dengan jenis-jenis kerang yang lainnya sehingga hasil penelitian yang didapatkan semakin baik lagi.

\section{Daftar Pustaka}

[1] T. Ojala, M. Pietikainen and T. Maenpaa, "Multiresolution gray-scale and rotation invariant texture classification with local binary patterns," IEEE Transactions on Pattern Analysis and Machine Intelligence, vol. 24, no. 7, pp. 971-987, 2002.

[2] M. Pietikäinen, T. Ojala and Z. Xu, "Rotation-invariant texture classification using feature distributions," Pattern Recognition, vol. 33, no. 1, p. 43-52, 2000. 
[3] Z. Guo, L. Zhang and D. Zhang, "A completed modeling of local binary pattern operator for texture classification," IEEE Transactions on Image Processing, vol. 19, no. 6, pp. 1657-1663, 2010.

[4] Y. Zhao, W. Jia, R.-X. Hu and H. Min, "Completed robust local binary pattern for texture classification," Neurocomputing, vol. 106, no. April, pp. 68-76, 2013.

[5] B. Smolka and K. Nurzynska, "Power LBP: A Novel Texture Operator for Smiling and Neutral Facial Display Classification," Procedia Computer Science, vol. 51, no. 2015, pp. 1555-1564, 2015.

[6] Z. Chen and S.-K. Sun, "A Zernike moment phase-based descriptor for local image representation and matching," IEEE Transactions on Image Processing, vol. 19, no. 1, pp. 205-219, 2010.

[7] M. Ghosh, J. Mukherjee and R. Parekh, "Fish Shape Recognition using Multiple Shape Descriptors," International Journal of Computer Applications, vol. 73, no. 16, pp. 14-19, 2013.

[8] A. Aakif and M. F. Khan, "Automatic classification of plants based on their leaves," Biosystems Engineering, vol. 139, no. November, pp. 66-75, 2015.

[9] D. Zhang and G. Lu, "Shape-based image retrieval using generic Fourier descriptor," Signal Processing: Image Communication, vol. 17, no. 10, pp. 825-848, 2002.

[10] A. Kadir, "Leaf identification using Fourier descriptors and other shape features," Gate to Computer Vision and Pattern Recognition, vol. 1, no. 1, pp. 3-7, 2015.

[11] M. Mentari, Y. A. Sari and R. K. Dewi, "Deteksi Kanker Kulit Melanoma dengan Linear Discriminant Analysis-Fuzzy k-Nearest Neigbhour Lp-Norm," Register: Jurnal Ilmiah Teknologi Sistem Informasi, vol. 2, no. 1, pp. 34-39, 2016.

[12] A. S. Nugroho, A. B. Witarto and D. Handoko, "Support Vector Machine - Teori dan Aplikasinya dalam Bioinformatika," 16 Maret 2005. [Online]. Available: http://www.komputasi.lipi.go.id/utama.cgi? tampilpublikasi\&1014224403\&1110939371 . [Accessed 2016 Juli 1]. 